\title{
STUDIES ON THE BOVINE SUBCLINICAL MASTITIS CAUSED BY STREPTOCOCCUS DYSGALACTIAE AND ITS PUBLIC HEALTH IMPORTANCE
}

\author{
GAADEE, H.I.M ${ }^{1}$ and MANAL M AMIN ${ }^{2}$ \\ ${ }^{1}$ Animal Health Research Institute, Biochemical Unit, Assiut Branch. \\ ${ }^{2}$ Animal Health Research Institute, Food Hygiene, Assiut Branch.
}

Received: 30 September 2018; Accepted: 30 October 2018

\begin{abstract}
The present study was conducted to investigate the effect of subclinical mastitis on clinic-pathological changes and public health importance in Mastitic cow. A total of 100 individual milk samples from clinically normal udder quarters of 100 dairy cow were collected and examined microbiologically as well as by using California Mastitis Test (CMT) for detection of subclinical mastitis and designing rapid diagnostic tests for other infection. The prevalence of Streptococcus species in the examined samples was (50\%), where, $17 \% S$. agalctiae, $10 \%$ S. dysgalactiae, $10 \%$., S. pyogenes, 2\%, S.Salivaris, 4\%., S. mitis, 3\% S. equi, 2\% S. mutans and $2 \%, S$. angionosus, respectively. Streptococcus dysgalactiae are Gram-positive bacterial pathogens that affect cows in dairy herds and considered as the major causes of economic losses of dairy producers without a control program, somatic cell count revealed highly significant increase in count $\geq 145.000$ cell than normal cows $<100.000$ cells. Two types of blood samples were analyzed for hematology and biochemical analysis (total protein, inorganic phosphorous and calcium. Also LDH (Lactate dehydrogenase enzyme) was detected, where the results indicated that there is highly significant decrease in HB (Hemoglobin) concentration, significant decrease of PCV (packed cell volume) and RBCs (Red blood cells) and significant increase in WBCs (White blood cells) in hematological analysis, while biochemical analysis revealed that, highly significant increase in LDH activity while a notable decrease in total protein and serum calcium were observed. However; Serum phosphorous level did not exhibit obvious changes.
\end{abstract}

Key word: Subclinical mastitis, beef cow, Streptococcus. dysgalactiae, Hematobiochmical analysis

\section{INTRODUCTION}

The main purpose of cow herds is production of healthy calves and milk. To keep calves healthy and fast growing a good start in life is of most importance. The milk production of the cow is considered to be an important factor affecting calf growth before weaning (Nickerson et al., 2000). Factors that reduce milk production may therefore have negative impact on calf weaning weights and public health. Bovine mastitis is an endemic disease of mammary glands, multifactorial disease often associated with bacterial intra-mammary infections (IMI), and may be responsible for a substantial proportion of the total production losses in dairy herds (Barkema et al., 2009). It has also been recognized as one of the most intractable health conditions in cows (Skuce et al., 2016), therefore it considered an impediment to perform an efficient and sustainable livestock production.

Corresponding author: Dr. MANAL M. AMIN

E-mail address: fathyahmad329@yahoo.com

Present address: Animal Health Research Institute, Food Hygiene, Assiut Branch.
The losses associated with bovine mastitis include reduction in milk yield, discharge of contaminated milk due to treatment with antibiotics, treatment losses and increases in mortality and replacement rates (Geary et al., 2012). If the disease occurs in the form of subclinical mastitis (SCM), no visible signs may be found in the udder or milk (International Dairy Federation, 2011). Milk from cows with SCM is characterized by increased lipolysis, proteolysis, rancidity and bitterness (Ma et al., 2000) and reduction in milk yield (Halasa et al., 2009). The reduction in milk yield and quality related to udder health are commonly calculated by somatic cell count (SCC) (Bartlett et al., 1990). The International Dairy Federation (2013) reports that the level of SCC in cows suffering from SCM is greater than 200,000 cells/ mL (milliliter). Also some studies reported that SCM causes increased SCC, impairs milk composition (Gonçalves et al., 2016; Bobbo et al., 2017) and milk yield (Botaro et al., 2015).

Intra-mammary infections are often described as subclinical or clinical mastitis. Subclinical mastitis is the presence of an infection without apparent signs of local inflammation or systemic involvement. 
Although transient episodes of abnormal milk or udder inflammation may appear, these infections are for the most part asymptomatic and, if the infection persists for at least 2 months, are termed chronic. Once established, many of these infections persist for entire lactations or the life of the cow, detection is best done by examination of milk for somatic cell counts (SCCs) (predominantly neutrophils) using either the California Mastitis Test or automated methods provided by dairy herd improvement organizations. SCCs are positively correlated with the presence of infection. Inflammatory changes and decreases in milk quality may start with SCCs as low as 100,000 cells $/ \mathrm{ml}$. Although variable change (especially if determined on a single analysis), an SCC of $\geq 280,000$ cells $/ \mathrm{mL}$ in a cow indicates a $>85 \%$ chance of being infected. Likewise, the higher the SCC in a herd bulk tank, the higher the prevalence of infection in the herd. Herd SCCs $<200,000$ cells $/ \mathrm{mL}$ are considered desirable, and lower counts can be attained while causative agents must be identified by bacterial culture of milk (Nickerson et al., 2000 and Watts, 1986).

Prevalence of IMI may vary markedly between herds, where it varied between $7 \%$ and $66 \%$ in some studies. Udder health is important for growth of beef calves, while subclinical mastitis or IMI in the dams have been associated with a 5-12\% reduction of calf weaning weight (Newman, 1991 and Nickerson et al., 2000). Where some (IMI) seem to have more negative effects on calf weaning weights than others (Nickerson et al., 2000), where cows with one or more blind quarters may also have calves with reduced growth (Duenas et al., 2001).

Diagnosis of pre acute california mastitis is given by clinical signs and hemato-biochemical findings (Akira, 1989). Thus the presence of endotoxin in blood plasma should be checked for the precise diagnosis of bovine pre-acute mastitis and characterized by severe quarter Inflammation (Schalm et al., 2006), stress in the form of muscular exertion causes alterations in the different blood constituents. (Cabona et al.,1990).

In this study, we aimed to assess the etiology of subclinical mastitis (SCM) in cows with the use of bacteriological and molecular identification methods, investigate clinic pathological changes among infected cow and some biochemical and hematological changes in infected beef cow with streptococcus dysgalactiae infection.

\section{MATERIALS AND METHODS}

\section{1-Animals:}

A total of 100 dairy milk cow with healthy clinically udder reared in private farm in Assiut Governorate were carried in these study.

\section{2- Samples:}

\section{2,a- Milk samples}

A total of 100 milk samples were collected from individual cows under complete aseptic condition (teat end was scrubbed with cotton soaked in $70 \%$ ethanol and the first drops of milk was discarded), $50 \mathrm{ml}$ of milk in sterile test tube and transferred immediately to the microbiological laboratory. Only milk with a California mastitis test (CMT) was subjected to bacteriological examination in this study. After cleaning of the udder by the milking personnel, a minimum of 10-15 streaks of milk were allowed to be milked before examination with CMT. Mid-stream milk from all quarters of the examined animals was checked with CMT. Milk was sampled for bacteriological examination in the same way as for clinical cases.

\section{2,b- Blood samples}

- $5 \mathrm{ml}$ blood samples from cows were collected by jugular venipuncture in test tubes with EDTA for hematological analysis;

- $5 \mathrm{ml}$ blood samples from cows were collected by jugular venipuncture in test tubes without EDTA, and centerifiguted at $3000 \mathrm{rpm}$ for preparation of serum to be used for biochemical analysis

\section{3- California mastitis test (CMT)}

California Mastitis Test (CMT) was adapted according to American Public Health Association APH (1978).

\section{4- Clinical examination:}

General condition of infected cows, including measurement of rectal temperature and palpation of the udder and clinical findings and CMT-score were recorded. If there were any signs of clot formation, discoloration, alterations in viscosity, aberrant smell or blood in the milk from any of the udder quarters were recorded, (Radostities, 2000).

\section{5- Bactriological examination}

One milliliter of the homogenized milk was aseptically inoculated into sterile cotton plugged test tube, containing $10 \mathrm{ml}$ of Dextrose azide broth and incubated at 37Ć for 24-48 hours. Each tube was examined for turbidity at the end of $24 \pm 2$ hours. If no turbidity is evident, the tubes were reincubated and read again at the end of $48 \pm 3$ hours. A loopfull from the incubated broth culture was then streaked onto plates of Streptococcus selective agar with 5$10 \%$ sheep blood. Streaked plates were incubated at $35 \pm 2^{\circ} \mathrm{C}$ aerobically, anaerobically, or under conditions of increased $\mathrm{CO} 2$ (5-10\%) and examined after 18 - 24 hours (Roantree et al., 1958). There are three types of hemolysis on blood agar media described by: (Isenberg, 1992).

\section{6- Biochemical reactions:}

All Streptococci isolates were catalase and oxidase negative. $S$. agalactiae isolates were beta hemolytic, 
able to hydrolyze $\mathrm{Na}$ hippurate and Arginine but unable to hydrolyses esculine. They could not ferment sorbitol, mannitol, arabinose, raffinose but ferment lactose and ribose. S.dysgalactiae isolates were alpha hemolytic, not able to hydrolyze $\mathrm{Na}$ hippurate and esculine but able to hydrolyze arginine and could not ferment sorbitol, arabinose, mannitol and raffinose but ferment lactose and ribose. All isolates ferment, sorbitol, mannitol and lactose. They were negative for fermentation of raffnose, ribose and arabinose. They can grow on $6.5 \mathrm{NaCl}$. All S.pyogenes isolates were beta hemolytic, could ferment lactose only. They were negative for $\mathrm{Na}$ hippurate and esculine hydrolysis but positive for arginine according, (Decker and Lohman., 1988).

\section{7- Somatic cell count:}

The methods available for assessing the SCC, indirectly estimation (e g. California Mastitis Test). With elevated SCC there is an increased risk that the quarter is harboring an infection.

\section{8- Hematological examination:}

A complete blood picture was manually performed according to (Jain., 1986).

\section{9- Biochemical examination:}

Calcium, Inorganic phosphorous, total protein, were determined in serum using kits from Bio Diagnostic Company, Egypt and measured by spectrophotometer. LDH in serum was measured by special kits according to methods of (Decker and Lohman., 1988).

10- Identification of bacteria by PCR amplification methods DNA Extraction:

DNA extraction from samples was performed using the QIA amp DNA Mini kit (Qiagen, Germany, $\mathrm{GmbH}$ ) with modifications from the manufacturer's recommendations. Briefly, $200 \mu \mathrm{l}$ of the sample suspension was incubated with $20 \mu \mathrm{l}$ of proteinase $\mathrm{K}$ and $200 \mu \mathrm{l}$ of lysis buffer at $56 \mathrm{C}$ for $10 \mathrm{~min}$. After incubation, $200 \mu 1$ of $100 \%$ ethanol was added to the lysate. The sample was then washed and centrifuged following the manufacturer's recommendations. Nucleic acid was eluted with $100 \mu$ l of elution buffer provided in the kit.

\section{Oligonucleotide Primer:}

Primers used were supplied from Metabion (Germany) and listed in Table (1).

\section{PCR amplification:}

Primers were utilized in a $25-\mu 1$ reaction containing $12.5 \mu \mathrm{l}$ of Emerald Amp Max PCR Master Mix (Takara, Japan), $1 \mu$ of each primer of $20 \mathrm{pmol}$ concentrations, $4.5 \mu \mathrm{l}$ of water, and $6 \mu \mathrm{l}$ of DNA template. The reaction was performed in an applied bio system 2720 thermal cycler.

\section{Analysis of the PCR Products:}

The products of PCR were separated by electrophoresis on $1.5 \%$ agarose gel (Applichem,
Germany, GmbH) in 1x TBE buffer at room temperature using gradients of $5 \mathrm{~V} / \mathrm{cm}$. For gel analysis, $20 \mu \mathrm{l}$ of the products was loaded in each gel slot. A Gelpilot 100 bp Ladder (Qiagen, Germany, GmbH) was used to determine the fragment sizes. The gel was photographed by a gel documentation system (Alpha Innotech, Biometra) and the data was analyzed through computer software.

\section{RESULTS}

\section{1- Bacteriological examination:}

In bacteriological culture of 100 milk samples, $S$. agalactiae isolated from 17 samples. S. dysgalactiae isolated from 10 samples, 10 with $S$. pyogenes, and each of $S$. salivaris and $S$. mutans isolated from two samples. The results are shown in Table 2.Furthur prognostic diagnosis have commonly been done based on clinical signs and hemato-biochemical examination.

\section{2- Somatic cell count:}

Somatic cell count in streptococcus dysgalactiae cow recommended number of cells $\geq 145.000 / \mathrm{ml}$, while with normal udder $<100.000$ cells $/ \mathrm{ml}$.

\section{3- Clinical examination:}

Subclinical mastitis is the most common form of mastitis. It is $15-40$ more common than clinical mastitis. There is no gross inflammation of the udder, no gross changes in the milk but there is decreased production and bad quality of milk. A subclinical mastitic cow may be diagnosed by the presence of signs of clot formation, discoloration, alteration in viscosity, aberrant smell or blood in the milk from any of the udder quarters, the animal was identified as subclinical case of mastitis, where reduction in yield potential due to the high SCC, and certainly represents a possible source of infection for other cows, who can become subclinical sufferers themselves, or may go on to show clinical signs of the illness, due to differences in immune status between cows.

\section{4- Hematological examination:}

- Hematological result illustrated in Table 3. Hematology showed a significant decrease in RBCs, PCV and highly significant decrease in hemoglobin while there was a significant increase in WBCs.

\section{5- Biochemical analysis:}

- Biochemical result illustrated in Table 4.

- Calcium and Inorganic phosphorous Slight significant decrease were recorded in calcium level while inorganic phosphorous revealed no obvious changes.

- Total protein values were significantly lower in mastitic cows $(\mathrm{p}<0.01)$.

- LDH level showed highly significant increase. 
Table 1: Primers sequences, target genes, amplicon sizes and cycling conditions.

\begin{tabular}{|c|c|c|c|c|c|c|c|c|c|}
\hline \multirow{2}{*}{$\begin{array}{l}\text { Target } \\
\text { Agent }\end{array}$} & \multirow{2}{*}{$\begin{array}{c}\text { Target } \\
\text { gene }\end{array}$} & \multirow{2}{*}{$\begin{array}{c}\text { Primers } \\
\text { sequences }\end{array}$} & \multirow{2}{*}{$\begin{array}{c}\text { Amplified } \\
\text { segment } \\
\text { (bp) }\end{array}$} & \multirow{2}{*}{$\begin{array}{c}\text { Primary } \\
\text { denaturation }\end{array}$} & \multicolumn{3}{|c|}{ Amplification ( 35 cycles) } & \multirow{2}{*}{$\begin{array}{c}\text { Final } \\
\text { extension }\end{array}$} & \multirow{2}{*}{ Reference } \\
\hline & & & & & $\begin{array}{c}\text { Secondary } \\
\text { denaturation }\end{array}$ & Annealing & Extension & & \\
\hline \multirow[t]{2}{*}{$\begin{array}{c}S . \\
\text { dysgalactiae }\end{array}$} & $\begin{array}{c}16 S \\
r R N A\end{array}$ & $\begin{array}{c}\text { GGAGTGGA } \\
\text { AAAT } \\
\text { CCACCAT }\end{array}$ & 549 & $\begin{array}{l}94^{\circ} \mathrm{C} \\
5 \mathrm{~min} .\end{array}$ & $\begin{array}{c}94^{\circ} \mathrm{C} \\
30 \mathrm{sec} .\end{array}$ & $\begin{array}{l}49.5^{\circ} \mathrm{C} \\
40 \mathrm{sec}\end{array}$ & $\begin{array}{l}72^{\circ} \mathrm{C} \\
45 \mathrm{sec}\end{array}$ & $\begin{array}{c}72^{\circ} \mathrm{C} \\
10 \mathrm{~min} .\end{array}$ & $\begin{array}{c}\text { Prabhu et } \\
\text { al., } 2013\end{array}$ \\
\hline & & $\begin{array}{c}\text { CGGTCAGGA } \\
\text { GGA } \\
\text { TGTCAAGAC }\end{array}$ & & & & & & & \\
\hline
\end{tabular}

Table 2: Prevalence of Streptococcus species among collected milk samples (no=100).

\begin{tabular}{ccc}
\hline Milk samples & Positive sampels & Percent of positive (\%) \\
\hline Streptoccous species & $\mathbf{1 7}$ & $\mathbf{1 7 \%}$ \\
\hline S. agalactiae & $\mathbf{1 0}$ & $\mathbf{1 0 \%}$ \\
\hline S. pyogenes & $\mathbf{1 0}$ & $\mathbf{1 0 \%}$ \\
\hline
\end{tabular}

\section{PCR results}

Out of 100 tested milk samples, S. dysgalactiae was detected by PCR in $6(6 \%)$. The PCR products obtained for the bacteria are shown in Fig. 1.

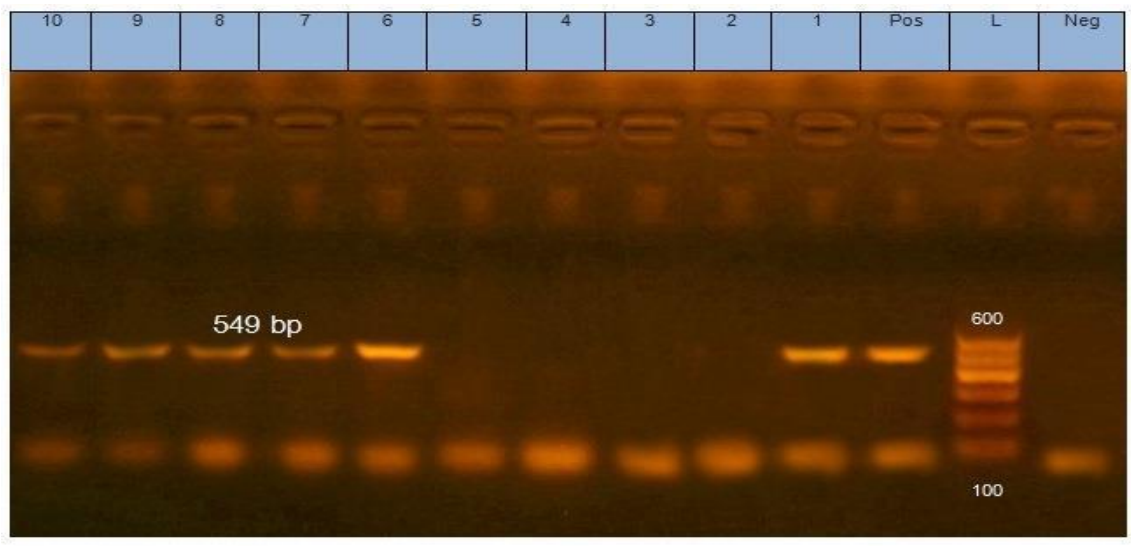

Fig. 1: PCR product

Table 3: Effect of mastitis on hematological parameters of infected cows $(n o=6)$. Significant $=(p \geq 0.5)$

\begin{tabular}{|c|c|c|}
\hline Animals & Control cow & Infected cow \\
\hline \multicolumn{3}{|l|}{ Parameters } \\
\hline $\mathrm{HB}(\mathrm{g} / \mathrm{dl})$ & $8.9 \pm 0.2$ & $6.80 \pm 0.58 \downarrow^{* *}$ \\
\hline $\operatorname{PCV}(\%)$ & $32 \pm 0.67$ & $30 \pm 0.07 \downarrow^{*}$ \\
\hline $\operatorname{RBCs}\left(10^{6} / \mathrm{ml}\right)$ & $9.6 \pm 0.74$ & $8.8 \pm 0.80 \downarrow^{*}$ \\
\hline WBCs $\left(10^{3} / \mathrm{ml}\right)$ & $10.00 \pm 0.74$ & $13.00 \pm 0.63 \uparrow^{*}$ \\
\hline
\end{tabular}

Table 4: Effects of subclinical mastitis on Biochemical changes in infected cow (no=6).

\begin{tabular}{ccc}
\hline Animals & Control cow & Infected cow \\
\hline Parameters & $7.79 \pm 0.14$ & $6.38 \pm 0.37 \downarrow^{*}$ \\
\hline Total protein & $67.00 \pm 0.23$ & $127 \pm 15.2 \uparrow^{* *}$ \\
\hline LDH $(\mathrm{u} / \mathrm{ml})$ & $8.13 \pm 1.52$ & $6.33 \pm 0.43 \downarrow^{*}$ \\
\hline Calcium $(\mathrm{mg} / \mathrm{dl})$ & $5.00 \pm 0.23$ & $4.91 \pm 0.97$ \\
\hline Phosphorus $(\mathrm{mg} / \mathrm{dl})$ &
\end{tabular}




\section{DISCUSSION}

Subclinical mastitis in cows is a major source of economic loss in the dairy production industry throughout the world. The prevailing pathogens (at various frequencies) isolated from the milk of cows with subclinical mastitis are streptococcal species, including $S$. agalactiae, $S$. dysgalactiae. and $S$. uberis. The most important streptococcal agents of bovine mastitis are $S$. agalactiae and S. dysgalactiae. $S$. agalactiae is a highly infectious pathogen that can rapidly spread among a herd from a single infected animal. The main source of the infection was the udder of infected cows. Although, when hygienic measure are poor, contamination of the environment may also provide an additional source (Radostits et al., 2000; Meiri-Bendek et al., 2002). S. dysgalactiae is the most commonly isolated environmental streptococci of bovine mastitis. $S$. dysgalactiae can also be found in the environment of dairy cattle and has been isolated from the tonsils, mouth, vagina and the mammary glands (Radostits et al., 2000). All of these bacteria are leading causes of both subclinical and clinical mastitis in dairy cattle worldwide. However, the importance of environmental pathogens has been raised relative to contagious pathogens. Good farming management and a high level of veterinary monitoring and treatment, may allow control of these pathogens in a herd. Therefore, early diagnosis of the presence of new infection in a herd is important for an effective control.

In the present study, S. agalactiae, S. dysgalactiae and $\mathrm{S}$. pyogenes were isolated by percentages of $17 \%, 10 \%$ and $10 \%$, respectively of milk samples (Table 2). This result was in agreement with the study of (Moatamedi et al., 2007), they isolated. S. agalactiae from 19 samples, $S$. dysgalactiae isolated from 10 samples, seven of which were CMTpositive and three were CMT-negative. Also agreement with (Keefe et al., 1997), they indicated that $\mathrm{S}$. agalactia was isolated from milk samples in a percentage of $18 \%$. Lower incidence of Streptococcus spp. in milk samples was recorded by (Olde Riekerink et al., 2006) and (Hawari and AlDabbas, 2008). A higher incidence of Streptococcus spp. in milk samples (59\%) was recorded by (Smith et al., 1985). Also the present study was agreement with (AbdeL-Tawab et al., 2017), they said that eighty one milk sample were positive for Streptococcus species with a percentage of $65.3 \%$ as the follow, $28.22 \%$ for $\mathrm{S}$. agalactiae, $11.29 \%$ for $\mathrm{S}$. dysgalactiae, $16.13 \%$ for S. uberis, $8.87 \%$ for $\mathrm{S}$. pyogenes, $0.81 \%$ for $\mathrm{S}$. pneumoniae. Bacteriological examination showed that most of the milk samples examined complied standards recommended by (International Dairy Federation, 2013). According to that standard method bacteria count on plate must not exceed $1 \times 10^{5} \mathrm{cfu} / \mathrm{ml}$ of milk. The low total counts of bacteria may reflect a good sanitation practices applied during milking. However, $6.1 \%$ and $8.2 \%$ (data not tabulated) of the examined milk samples in cows, exceeded the upper border line of standards recommended by Milk Quality Program (Barbano 1992). The high counts of bacteria in some of milk samples are attributed to mastitis. Such milk may often be used directly as a drink, and constitute a public health concern. It is epidemiologically significant that not only animals, but also humans carry E. coli in their gastrointestinal tract. The occurrence of coliforms in milk may, therefore, be considered as a real indicator of the fecal pollution with the possibly existing associated pathogens. The public health hazard of bacteria has been emphasized by many authors, because these bacteria have been implicated in human cases of gastroenteritis, epidemic diarrhea in infants, sporadic diarrhea in children as well as in cases of food poisoning (Mossel, 1982).

Riffon et al. (2001), developed a PCR method to identify with rapidity, sensitivity, and specificity the major pathogens involved in intra-mammary infections in cows including $\mathrm{S}$. agalactiae, S. dysgalactiae and S. uberis. The primers used for detection of S. agalactiae and S. dysgalactiae were designed based on the 16S rRNA gene and that for S. uberis was based on the $23 \mathrm{~S}$ rRNA gene. Their results showed that these specific primers can discriminate close phylogenetic bacterial species (S.agalactiae and S. dysgalactiae). The specificity of the primers has also been tested with DNA from different bacterial species (Forsman et al., 1997). Therefore, it is impossible that there were false positive results in our study. On the other hand, the absence of PCR product in our negative control shows that there was not any contamination during the PCR assay and rejects any possible false positive results. In addition, amplification of the expected PCR product by the primers specific for the mitochondrial cytochrome B gene suggests that the DNA extraction has been successfully performed and there was not any fault in the amplification reaction. (Meiri-Bendek et al., 2002) developed a PCR-based on the 16S rRNA gene sequence for diagnosis of S. agalactiae in cow's milk. Their results showed that this PCR assay can determine one infected quarter among 125 milk samples or one infected cow among 500 cows. Therefore, the PCR has enough sensitivity and specificity for the diagnosis of $\mathrm{S}$. agalactiae in milk samples and is more sensitive than bacterial culture. They concluded that with this method, the definite diagnosis can be made in few hours and so enable us to do monthly or even weekly testing on bulk milk samples. In this way, the first cases of infection in herd can be diagnosed and with aggressive monitoring and treatment may be able to completely eradicate this pathogen from herds. Hence we can see, the results of other researchers are in agreement with the results of this study and suggest that PCR, 
as a molecular diagnostic method, can be used as a rapid diagnostic method for bovine mastitis with high sensitivity and specificity.

Hematological and biochemical investigations for confirmation of diagnosis given by (CMT). It is clear that incidence of subclinical mastitis among examined dairy cows is relatively high with reduction in milk yield which causes a heavy economic losses. The colonization of mammary glands by pathogenic microorganism's results in a series of events which lead to major alterations of milk compositions secreted from cells. Therefore CMT is a suitable measure for use on large scales monitoring programs. (Ederhart, 2007).

Somatic cell count (SCC) can be used to monitor the status of SCM in herds or individual cows which are an important component of assessing milk quality, hygiene and mastitis control (Sharma et al., 2011). An elevated somatic cell count (SCC) is almost always caused by mastitis and SCC can therefore be used as an indicator of udder health. However, the SCC might also be elevated to some extent for other reasons, for example immediately after calving and at the end of lactation. Otherwise, the SCC remains constantly low during lactation in a healthy cow (Harmon, 1994). Elevated SCC's are correlated to reduced productivity and milk quality and may also indicate poor animal welfare (Kehrli and Shuster, 1994). At mid-lactation, the SCC is normally < 100 $000 / \mathrm{ml}$ and in a healthy udder quarter the somatic cells are mainly of macrophage origin where in milk from a mastitis udder quarter, $90 \%$ of the somatic cells are of neutrophil origin (Broom, 2006). In the present study, SCC in infected cow revealed high number of cells $\geq 145,000$ cells/ $\mathrm{ml}$ than control cow which revealed cells $<100,000$ cells $/ \mathrm{ml}$ and that coincide with (Svensk Mjölk, 2010). The high SCC is mostly related to the presence of microorganism in the udder but also the type of microbes could affect the SCC in milk (Ariznabarreta et al., 2002). The major pathogens generally cause the greatest SCC increase and infection by minor pathogens usually causes considerably less SCC elevation and rarely result in clinical mastitis (Supr et al., 2011). In some cases, high SCC is detected in milk samples without presence of microorganisms and it does not indicate that the gland is healthy (McDougall et al., 2001). However, cows with low SCC can also harbor the mastitis pathogen (Katsande et al., 2013). Therefore, bacteriologic culture is necessary to accurately diagnose the source of the mastitis even though SCC profiles suggest lower probability of SCM.

Prognostic diagnoses have commonly been done on cow with clinical symptoms, in addition to hematological and biochemical examinations of blood. Biochemical analysis of mastitis animals may help in diagnosis of subclinical mastitis and become a helpful means for practice under field conditions
(Rose, 1987). The present results in subclinical mastitis cows fell in the range given by (Jain, 1986) and (Kaneko., 1989). As shown in Table 3and 4 the significant changes $(\mathrm{p} \geq 0.5)$ in hem gram and other biochemical values are due to infection with streptococcus dysgalactiae (subclinical mastitis). In the present study we have shown that LDH activities were enhanced in mastitic cows. The enhancement can be at least partly explained by the participation of leucocytes in milk (Kerumori et al., 1989).

Protein concentration was significantly decreased while somatic cell count and LDH are increased when compared to normal cows. In the present investigation we have also measured LDH of Streptococcus dysgalactiae species of bacteria which were isolated from the subclinical mastitic milks, where its activities were much higher in case of the infected udders as compared to the control as illustrated in Table 4 . We could not determine the pattern of mastitic udders because the udders contained large number of leucocytes.

\section{CONCLUSION}

Conclusively, in mastitic animals the application of C.M.T. leads to early detection of subclinical infected quarters and aids in the selection of dairy animals for either isolation or therapy. Also we conclude that mastitis causes anemia in cows detected by decrease of hemoglobin, $\mathrm{RBC}^{\mathrm{S}}$, and PCV, LDH activity in serum increases, as well as calcium in serum.

\section{RECOMMENDATIONS}

Good farming management and a high level of veterinary monitoring and treatment, may allow control of these pathogens in a herd. Therefore, early diagnosis of the presence of new infection in a herd is important for an effective control. Here follows a proposal of protective measures that could improve the general udder health and milk production:

1- Improve hygienic measures during milking by;

- Proper washing of hands before milking and between animals

- Only using clean water and separate towels for cleaning the udders

- Implementing the use of teat-dip after milking

- Keeping animals from lying down immediately after milking

2- Divide herd into groups according to udder status in order to establish a milking order

3- Implement correct and gentle milking technique 
4-Apply correct treatment of mastitis based on bacteriological culturing by consulting a veterinarian

5- Do not keep high parity cows with a poor udder health

6- Improve feeding routines

7- Implement lactation periods with recurrent dry periods in between

8- Improve record keeping at farms and for practicing veterinarians in order to gain statistics on health status of dairy cattle in herds and on a national level.

9- Periodical hygienic management with udder before milking to avoid intra-mammary infection.

10- Periodical uses of California Mastitis Test in the farm helped in early detection of subclinical mastitis.

11- Periodical examination of udder and milk to early detection of subclinical mastitis to keep on the quality and quantity of milk.

\section{REFERENCE}

Abdel-Tawab, A.; Abou El-Roos, N.A.; El-Hofy F.I. and Hassnaa, E. Abdullah (2017): Molecular studies regarding to virulence factors of Streptococcus species isolated from raw milk. Benha. Veterinary. Medical. Journal (32). NO. 1: 145- 152, march, 2017.

American Public Health Association APH (1978): "Standard Methods for Examination of Dairy. Products" 14th ed., Amer public health Ass. Washington.

Akira, A. (1989): Detection endotoxin in affected milk from cows with coliform mastitis, Japanese. J. Vet Science 41 (4) 845

Ariznabarreta, A.; Gonzal, C. and Primitivo O.F.S. (2002): Microbiological quality and somatic cell count of ewe milk with special reference to Staphylococci. J. Dairy Sci., 85: 1370 1375.

Barbano, D.M. (1992): Raw milk quality: Milk quality improvement in the United States. Australian Journal of Dairy Technology 47, 89-90.

Barkema, H.W.; Green, M.J.; Bradley, A.J. and Zadoks, R.N. (2009): Invited review: the role of contagious disease in udder health. J. Dairy Sci. 92 (10), 4717-4729. http://dx.doi. org/10.3168/jds. 2009-2347.

Bartlett, P.C.; Miller, G.Y.; Anderson, C.R. and Kirk, J.H. (1990): Milk production and somatic cell count in michigan dairy herds. J. Dairy Sci. 73 (10), 2794-2800.
Bobbo, T.; Ruegg, P.L.; Stocco, G.; Fiore, E.; Gianesella, M.; Morgante, M.; Pasotto, D.; Bittante, G. and Cecchinato, A. (2017): Associations between pathogen-specific cases of subclinical mastitis and milk yield, quality, protein composition and cheese-making traits in dairy cows. J. Dairy Sci. 100 (6), 48684883.

Botaro, B.G.; Cortinhas, C.S.; Dibbern, A.G.; Prada e Silva, L.F.; Benites, N.R. and Dos Sandos, M.V. (2015): Trop. Anim. Health. Prod. 47, 61-66.

Broom, D.M. (2006): Behavior and welfare in relation to pathology. Applied Animal Behaviour Science 97, 73-83.

Cabona, E.M.; Adriano, E.A. and Encarnacion, R.O. (1990): Hematologic observations on swamp buffallow harvested to increase on pulling, lodes Buff allow Bull. 9, 27.

Decker, T. and Lohmann-Matthes, M.L. (1988): A quick and simple method for the quantitation of lactate dehydrogenase release in measurements of cellular cytotoxicity and tumor necrosis factor (TNF) activity. J Immunol Meth.115: 61-9.

Duenas, M.L.; Paape, M.J.; Wettemann, R.P. and Douglass, L.W. (2001): Incidence of mastitis in beef cows after intramuscular administration of oxy-tetracycline. J. Anim. Sci 2001, 79: 1996-2005.

Ederhart, R.J. (2007): Am. Vet. Med. Assoc. 206, 1973.

Forsman, A.; Tilsala-Timisjärvi, P.A. and Alatossava. T. (1997): Identification of staphylococcal and streptococcal causes of bovine mastitis using 16S-23S rRNA spacer regions. Microbiology. 143: 3491-3500.

Geary, U.; Lopez-Villalobos, N.; Begley, N.; McCoy, F.; O'Brien, B.; O'Grady, L. and Shalloo, L. (2012): Estimating the effect of mastitis on the profitability of Irish dairy farms. J. Dairy Sci. 95 (7), 3662-3673.

Gonçalves, J.L.; Tomazi, T.; Barreiro, J.R.; Beuron, D.C.; Arcari, M.A.; Lee, S.H.I.; De Magalhães Rodrigues Martins, C.M.; Araújo Junior, J.P. and Dos Santos, M.V. (2016): Effects of bovine subclinical mastitis caused by Corynebacterium spp. on somatic cell count, milk yield and composition by comparing contralateral quarters. Vet.

Harmon, R.J. (1994): Somatic cell counts. Journal Physiology of mastitis and factors affecting of Dairy Science 77, 2103-2112.

Halasa, T.; Nielen, M.; De Roos, A.P.W.; Van Hoorne, R.; De Jong, G.; Lam, T.J.G.M.; Van Werven, T. and Hogeveen, H. (2009): Production loss due to new subclinical mastitis in Dutch dairy cows estimated with a test-day model. J. Dairy Sci. 92 (2), 599-606.

Hawari, A.D. and Al-Dabbas, F. (2008): Prevalence and distribution of mastitis 
pathogens and their resistance against antimicrobial agents in dairy cows in Jordan. American Journal of Animal and Veterinary Sciences, 3: 36-44.

International Dairy Federation (2011): Suggested Interpretation of Mastitis Terminology (revision of Bulletin of IDF No. 338/1999).

Bulletin of the IDF No. 448.

International Dairy Federation (2013): Guidelines for the Use and Interpretation of Bovine Milk Somatic Cell Counts (SCC) in the Dairy Industry. Bulletin of the I D F No. 466/2013. International Dairy Federation, Brussels, Belgium.

Isenberg, H. (1992): Interpretation of aerobic bacterial growth on primary culture media, Clinical microbiology procedures handbook. American Society for Microbiology, Washington, DC, 10: 65-72.

Jain, W.C. (1986): "Schalm's Vet Hematology"4th ed lee and Febiger Philedelphia U.S.A.

Katsande, S.; Matope, G.; Ndengu, M. and Pfukenyi, D.M. (2013): Prevalence of mastitis in dairy cows from small holder farms in Zimbabwe. Onderstepoort J Vet Res., 80(1): 523- 529. http://dx.doi. Org / 10 .4102 / ojvr. v80i1.523

Keefe, GP. (1997): Streptococcus agalactiae mastitis: a review. Can. Vet. J., 38: 429-437.

Kehrli, M.E., Jr. and Shuster, D.E. (1994): Factors affecting milk somatic cells and their role in health of the bovine mammary gland. Journal of Dairy Science 77, 619-627.

Kerumori, K.; Kanae, M. and Mario, K. (1989): Contribution of leucocytes to the origin of lactatedehydrogenase by isoenzymes in milk of bovine, Mastitis. Japanese Journal of Vet Science, 530.

Koneko, J.J. (1989): Clinical Biochemistry of Domestic Animals 4th ed Academic press In New. York. U.S.A.

Ma, Y.; Ryan, C.; Barbano, D.; Galton, D.; Rudan, M. and Boor, K. (2000): Effects of somatic cell count on quality and shelf-life of pasteurized fluid milk. J. Dairy Sci. 83 (2), 264-274.

McDougall, S.; Murdough, P.; Pankey, W.; Delaney, C.; Barlow, J. and Scruton, D. (2001): Relationship among somatic cell count, California mastitis test, impedance and bacteriological status of milk in goats and sheep in early lactation. Small Rumin Res, 40: 245-254.

Meiri-Bendek, I.; Lipkin, E.; Friedmann, A.; Leitner, G.; Saran, A.; Friedman, S. and Kashi, Y. (2002): A PCR-based method for the detection of Streptococcus agalactiae in Milk. J. Dairy Sci., 85: 1717-1723.

Mossel, D.A.A. (1982): Microbiology of Food. 3rd Ed., University of Utrecht, The Netherlands ISBN.
Moatamedi, H.I.; Seyfiabad Shapouri, M.I; Ghorbanpoor, M.I.; Jamshidian, M.I. and Gooraninejad, S.A. (2007): polymerase chain reaction based study on the subclinical mastitis caused by Streptococcus agalactiae, S. dysgalactiae and S. uberis in cattle in Ahvaz Iranian Journal of Veterinary Research, University of Shiraz, Vol. 8, No. 3, Ser. No. 20

Newman, M.A.; Wilson, L.L.; Cash, E.H.; Eberhart, R.J. and Drake, T.R. (1991): Mastitis in beef cows and its effects on calf weight gain. J. Anim. Sci 1991, 69: 4259-4272.

Nickerson, S.C.; Owens, W.E. and DeRouen, S.M. (2000): Mastitis prevalence in first calf beef heifers and effect on calf weaning weight. Large Anim Pract 2000, 21: 20-23.

Olde Riekerink, R.G.; Barkema, H.W.; Veenstra, S.; Poole, D.E.; Dingwell, R.T. and Keefe, G.P. (2006): Prevalence of contagious mastitis pathogens in bulk tank milk in Prince Edward Island. Can Vet J, 47: 567-572.

Radostits, OM.; Gay, CC.; Blood, DC. and Hinchcliff, $K W$. (2000): Veterinary medicine. 9th. Edn. London, UK, W.B. Saunders Co., PP: 603-653.

Riffon, R.; Sayasith, K.; Khalil, H.; Dubreuil, P.; Drolet, M. and Lagacé, J. (2001): Development of a rapid and sensitive test for identification of major pathogens in bovine mastitis by PCR. J. Clin. Microbiol., 39: 2584-2589.

Roantree, R.; Rantz, L. and Haines, E. (1958): A medium containing nucleic acid, maltose, and antibiotics for the isolation of group A hemolytic streptococci. The Journal of Laboratory and Clinical Medicine, 52: 496500

Rose, R.J. (1987): Poor performance syndrome investigation and diagnostic technologies in current therapy in equine medicine, (Ed) W.E Robinoson, Philadelphia W.B. Saunders.

Schalam, O.W.; Caroll, E.J. and Jain, W.C. (2006): Bovine Mastitis. Febriger. Philadelphia.

Sharma, N.; Singh, N.K. and Bhadwal, M.S. (2011): Relationship of Somatic Cell Count and Mastitis: An Overview. Asian- Australas J Anim Sci., 24: 429-438.

Skuce, P.J.; Bartley, D.J.; Zadoks, R.N. and Macleod, M. (2016): Livestock Health and Greenhouse Gas Emissions. ClimateXchange, Scotlans's Centre of Expertise on Climate Change.

Smith, K.L.; Todhunter, D. and Schoenberger, P. (1985): Environmental Mastitis: Cause, Prevalence, Prevention. Journal of Dairy Science, 68: 1531-1553.

Supr, K.; Haesebrouck, F.; Zadoks, R.N.; Vaneechoutte, M.; Piepers, S. and Vliegher. S. De. (2011): Some coagulase-negative Staphylococcus species affect udder health 
more than others. J. Dairy Sci., 94: 23292340.

Svensk Mjölk-Swedish Dairy Association (2010): Förebyggande åtgärder minskar risken för juverinflammation. [online] (2010) Available from: $\quad$ http://www. svenskmjolk.se/
Mjolkgarden/Djurvalfard/Sjukdomar/Juverinf lammation/ [2013-02-05].

Watts, J.L.; Pankey, J.W.; Oliver, W.M.; Nickerson, S.C. and Lazarus, A.W. (1986): Prevalence and effects of intra-mammary infection in beef cows. Anim. Sci. J. 1986, 62: 16-20.

\section{دراسات على التهاب الضرع الذفى فى الابقار المسبب استربت ديسجلاكتيا وأهميته على الصحة العامة هلى ابراهيم مصطفى جعيإى ، منال محمد /مين عبد الرحيم}

Email: fathyahmad329@yahoo.com Assiut University web-site:www.aun.edu.eg

اجريت الدراسة الحالية لمعرفة تأثير التهاب الضرع الخفى فى الابقار على التغيرات المرضية والاكلينيكية وأهميته على الصحة

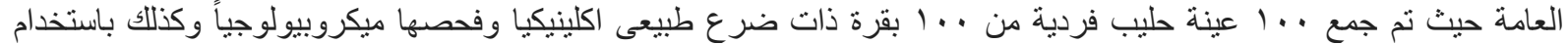
اختبار التهاب الضرع كاليفورنيا (CMT) للكثف عن التهاب الضرع الضرع الخفى واجر اء اختبار ات التشخيص السريع للعدوى الأخرى.

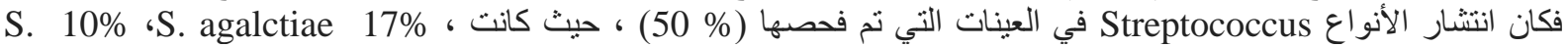
، 2\% و S. mutans 2\% ،S. equi 3\% ،S. mitis ، 4\%. ‘S.Salivaris ،2\% ،S. pyogenes ، 10\% ،dysgalactiae

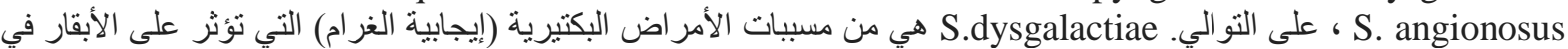

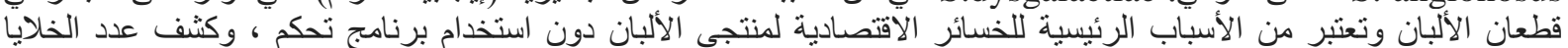

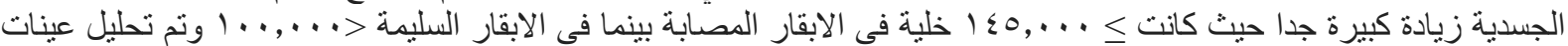

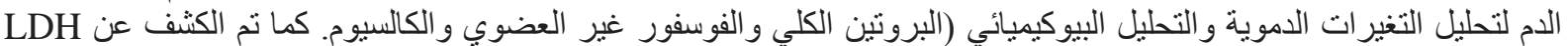

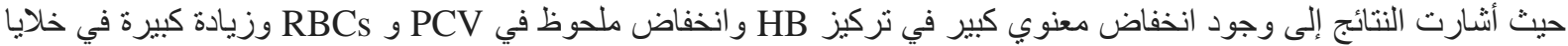

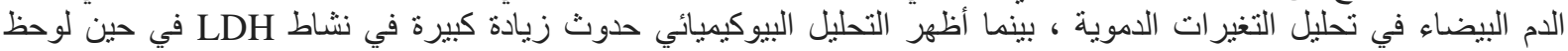

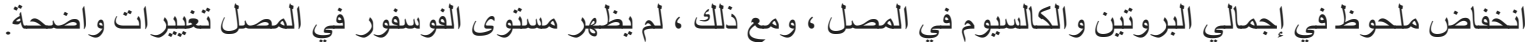
الكلمات الدالة: التهاب الضرع الخفى ، الابقار ، استربت ديسجلاكتيا ، تحليل الدموى و البيوكيميائى. 